Плодоводство и виноградарство Юга России № 65(5), 2020 г.

УДК 634.86:631.524.7(470.61)

UDC 634.86:631.524.7(470.61)

DOI 10.30679/2219-5335-2020-5-65-127-140

DOI 10.30679/2219-5335-2020-5-65-127-140

УВОЛОГИЧЕСКАЯ ОЦЕНКА

СТОЛОВЫХ СОРТОВ ВИНОГРАДА

НА КОЛЛЕКЦИИ

В НИЖНЕМ ПРИДОНЬЕ*

Наумова Людмила Георгиевна

канд. с.-х. наук

ведущий научный сотрудник

лаборатории ампелографии

e-mail: LGnaumova@yandex.ru

Ганич Валентина Алексеевна

канд. с.-х. наук

ведущий научный сотрудник

лаборатории ампелографии

e-mail: ganich1970@yandex.ru

Всероссийский научно-

исследовательский институт

виноградарства и виноделия

имени Я.И. Потапенко - филиал

Федерального государственного

бюджетного научного учреждения

«Федеральный Ростовский

аграрный научный центр»,

Новочеркасск, Россия

Приведены результаты изучения в 2017-2019 гг. увологических показателей столовых сортов винограда, произрастающих на Донской ампелографической коллекции имени Я.И. Потапенко (г. Новочеркасск, Ростовская область). Сорта изучались в привитой культуре на подвое Берландиери $\times$ Рипариа Кобер 5ББ. Схема посадки кустов 3,0 × 1,5 м. Культура неполивная. Изучение сортов винограда проводили с использованием общепринятых в виноградарстве методик и ГОСТов.

\section{UVOLOGICAL EVALUATION \\ OF TABLE GRAPE VARIETIES \\ ON THE COLLECTION \\ OF THE LOWER DON REGION*}

\author{
Naumova Lyudmila Georgievna \\ Cand. Agr. Sci. \\ Leading Research Associate \\ of Ampelographic Laboratory \\ e-mail: LGnaumova@yandex.ru \\ Ganich Valentina Alekseyevna \\ Cand. Agr. Sci. \\ Leading Research Associate \\ of Ampelographic Laboratory \\ e-mail: ganich1970@yandex.ru
}

\author{
All-Russian \\ Research Institute \\ named after Ya.I. Potapenko \\ for Viticulture and Winemaking - \\ Branch of Federal State \\ Budget Scientific Institution \\ «Federal Rostov Agricultural \\ Research Center», \\ Novocherkassk, Russia
}

The paper presents the results of the study of uvological indicators of table grape varieties carried out in 2017-2019 on the Don ampelographic collection named after Ya.I. Potapenko (Novocherkassk, Rostov Region). The varieties were studied in grafted culture on the rootstock of Berlandieri $\times$ Riparia Kober 5BB. Planting scheme was $3.0 \times 1.5 \mathrm{~m}$, non-watering culture. The study of grape varieties was carried out using generally accepted methods in viticulture and State Standards.

\footnotetext{
* Работа выполнена при поддержке гранта Российского фонда фундаментальных исследований № 18-016-00213.

* This work was carried supported by the Russian Foundation for Basic Research grant№ 18-016-00213.
} 
На дегустации свежих ягод были представлены 64 сортообразца винограда из коллекции, из них 9 - бессемянные. Выполнены промеры гроздей и ягод, определена средняя масса ягоды и кондиции урожая (сахаристость сока ягод и титруемая кислотность), проведено ранжирование сортов по этим показателям. Наиболее крупные грозди были у сортов винограда Валентина, Октябренок, Мускат дербентский, Заря Несветая, Аку-Аку (длина грозди 24 см и более). Методы оценки качества столовых сортов винограда основаны на субъективном анализе и на инструментальных измерениях, которые коррелируют с органолептическими свойствами и могут использоваться в качестве предикторов потребительской приемлемости. Наибольшая средняя масса ягоды была у сортов винограда Валентина (11,5 г), Маршальский $(8,3$ г), Надежда АЗОС, Русмол $(8,1$ г), Барт (7,9 г), Кардинал устойчивый $(7,4$ г), Блек роуз $(7,1$ г), Заря Несветая (7,0 г). По данным проведенных исследований, выделились по комплексу увологических показателей (дегустационная оценка свежего винограда, размеры грозди и ягоды, масса ягоды, кондиции урожая) столовые сорта: Валентина, Памяти Негруля, Надежда A3OC, а также бессемянные Кишмиш лучистый, Сублима сидлис, Арсеньевский.

Ключевые слова: УВОЛОГИЧЕСКАЯ ОЦЕНКА, ВИНОГРАД, СОРТ, АМПЕЛОГРАФИЧЕСКАЯ КОЛЛЕКЦИЯ, ДЕГУСТАЦИОННЫЕ ОЦЕНКИ, КОНДИЦИИ УРОЖАЯ, РАЗМЕРЫ ГРОЗДЕЙ И ЯГОД
At the tasting of fresh berries, 64 varieties were presented from the collection, 9 of them were seedless. Measurements of bunches and berries were made, the average weight of berries and crop conditions were determined (sugar content of berry juice and titrated acidity), and varieties were ranked according to these indicators. The largest bunches were in the grape varieties of Valentine, Oktyabrenok, Muscat Derbentskiy, Zarya Nesvetaya, Aku-Aku (the length of the bunch is $24 \mathrm{sm}$ or more). Methods for the quality assessing of table grapes are based on subjective analysis, and on instrumental measurements that correlate with organoleptic properties and can be used as predictors of consumer acceptability. The highest average weight of the berry was in the grape varieties of Valentina (11.5 g), Marshalsky (8.3 g), Nadezhda AZOS, Rusmol (8.1 g), Bart (7.9 g), Cardinal Ustoychiviy (7.4 g), Black Rose (7.1 g), Zarya Nesvetaya $(7.0 \mathrm{~g})$. According to the research, a number of table varieties stand out due to a set of morphological (tasting evaluation of fresh grapes, size of buncheas and berries, berry weight, crop conditions): Valentina, Pamyati Negrulya, Nadezhda AZOS as well as the seedless grapes of Kishmish Luchistiy, Sublima Seedless, Arsenevsky.

Key words: UVOLOGICAL EVALUATION, GRAPES, VARIETY, AMPELOGRAPHIC COLLECTION, TASTING ASSESSMENTS, CROP CONDITIONS, SIZE OF BUNCHES AND BERRIES

Введение. Развитие фундаментальных исследований в области сельского хозяйства является необходимым условием для создания новых кон- 
курентоспособных сортов и гибридов сельскохозяйственных культур в целях решения проблемы продовольственной безопасности страны и обеспечения населения качественными продуктами питания. Предметом этих исследований являются генетические ресурсы растений, которые приобрели исключительное научное и народнохозяйственное значение для Российской Федерации [1].

В современном отечественном виноградарстве острой проблемой является совершенствование сортимента для создания высокоадаптивных насаждений и устойчивого производства конкурентоспособного винограда в нестабильных стрессовых погодных условиях умеренно континентального климата юга России. В этой связи актуально изучение происхождения, формирования и сохранения генетических ресурсов в целях их вовлечения в селекционный процесс для решения важнейших народно-хозяйственных задач. Возрастает роль сорта и ампелографических коллекций [2]. Мобилизация и размещение генетических ресурсов в ампелографических коллекциях играет важную роль в сохранении генофонда винограда.

Увология - наука о структурных компонентах грозди и ягод винограда; химико-технологическая дисциплина, изучающая виноград как сырье для пищевой промышленности [3]. Изучение винограда как исходного материала для того или иного вида использования составляет предмет увологии. Термин «увология» и методика увологического описания сортов винограда предложены советским учёным Н.Н. Простосердовым. Основное положение увологии заключается в том, что хозяйственно-технологические свойства винограда определяются особенностями сорта, природными условиями и способами его выращивания [4].

Изучение механического состава грозди позволяет установить соотношение массы грозди, гребня (скелет грозди) и ягод, а у ягод - и соотношение массы кожицы, мякоти, семян и сока. Анализ механических свойств 
Плодоводство и виноградарство Юга России № 65(5), 2020 г.

ягод дает возможность определить прочность их прикрепления к плодоножкам и сопротивляемость ягод раздавливанию.

Увология включает также изучение химического состава ягод винограда, динамику их созревания и органолептическую оценку сорта, она дополняет ампелографию и помогает выявить способы наилучшего и наиболее полного хозяйственного использования различных сортов винограда. На основании данных увологии в пищевой промышленности разрабатывается соответствующая сорту винограда технология его переработки $[5,6]$.

Органолептическая оценка, анализ химического состава, механических свойств важны для понимания конечной ценности свежего винограда и определяются широким диапазоном современных методов [7].

Твёрдость ягоды считается мерой свежести и является одним из наиболее актуальных признаков для селекции столового винограда, так как высокая степень твёрдости, требуемая потребителями, также гарантирует качество ягод в процессе послеуборочной обработки (манипуляции и транспортировки), что важно для производителей [8]. Механическая устойчивость грозди и ягоды зависит от сорта винограда, региона произрастания, метеорологических условий года [9-16].

Изменения климата влияют на все характеристики винограда, включая качество свежих ягод и вина [17-19]. Ранее (Новикова, Наумова, 2013) методами регрессионного анализа показали, что сильное влияние на сахаристость и кислотность оказывает соотношение количества осадков и суммы температуры воздуха в периоды с температурами выше 15 и $20^{\circ} \mathrm{C}$. Наиболее значимо влияние ГТК за период с температурами выше $15^{\circ} \mathrm{C}$ [20].

Цель данных исследований - выделить столовые сорта винограда с высокими увологическими показателями. 
Объекты и методы исследований. Изучение сортов винограда проводили в 2017-2019 гг. на Донской ампелографической коллекции имени Я.И. Потапенко (г. Новочеркасск, Ростовская область). Сорта изучались в привитой культуре на подвое Берландиери $\times$ Рипариа Кобер 5ББ. Схема посадки кустов 3,0 × 1,5 м. Культура неполивная. Грунтовые воды залегают на глубине 15-20 м и не оказывают влияния на развитие виноградных кустов. Технология возделывания виноградников общепринятая для северной зоны промышленного виноградарства РФ. Изучение сортов проводили с использованием общепринятых в виноградарстве методик $[12,21,22]$ и ГОСТ (сахаристость сока ягод определяли по ГОСТ 27198-87, титруемую кислотность - ГОСТ 32114-2013).

Оценка образцов свежих ягод проводилась на закрытых научных дегустациях (по 10-балльной шкале) членами дегустационной комиссии (утвержденной приказом директора института). Оценка эксперта получается сложением баллов за определенные характеристики. Оценка сорта усреднением баллов экспертов, минимальный и максимальный экспертные баллы не учитываются.

Объектом исследований были столовые, бессемянные и универсальные сорта винограда, и представленные на дегустациях свежих ягод, их размерные характеристики, дегустационные оценки, кондиции урожая.

Обсуждение результатов. Важным этапом сортоизучения является оценка качества урожая, которая позволяет определить направленность сорта, выращенного в климатических условиях региона произрастания. Помимо химического и механического анализов качество урожая сортов винограда, предназначенных для потребления в свежем виде, оценивают органолептически, то есть при помощи органов чувств - зрения, обоняния, вкуса. Этот способ оценки называют дегустацией [22]. 
Плодоводство и виноградарство Юга России № 65(5), 2020 г.

На дегустации свежего винограда (табл. 1) в 2017-2019 гг. были представлены 64 сортообразца с коллекции, из них 9 - бессемянных (Арсеньевский, Кишмиш лучистый, Кишмиш розовый, Коринка русская, Мечта, Ромулус, Сублима сидлис, Эйнсет сидлис, Эльф), 21 сорт селекции ВНИИВиВ-филиал ФГБНУ ФРАНЦ, а также интродуцированные сорта.

Таблица 1 - Дегустационные оценки свежего винограда (среднее за 2017-2019 гг.)

\begin{tabular}{|c|c|}
\hline $\begin{array}{l}\text { Дегустационная } \\
\text { оценка, балл }\end{array}$ & Сорт, форма \\
\hline 9,0 & Кишмиш лучистый, Сублима сидлис \\
\hline 8,9 & Арсеньевский, Кишмиш розовый, Памяти Негруля \\
\hline 8,8 & Золотой Дон \\
\hline 8,7 & Валентина, Мечта, Памяти Лазаревского \\
\hline 8,6 & Надежда АЗОС, Оли коки, Памяти Кострикина \\
\hline 8,5 & Ани, Победа \\
\hline 8,4 & $\begin{array}{l}\text { Барт, Долорес, Заря Несветая, Мускат де Кодру, Оригинал, } \\
\text { Талисман, Шоколадный }\end{array}$ \\
\hline 8,3 & Геркулес, Коринка русская, Мускат смедеревский, Эйнсет сидлис \\
\hline 8,2 & $\begin{array}{l}\text { Агат донской, Кардинал, Кардинал устойчивый, Маршальский, } \\
\text { Октябренок, Таир, Тасон, Томайский, Юбилей Журавеля }\end{array}$ \\
\hline 8,1 & $\begin{array}{l}\text { Восторг, Звездный, Золотинка, Краса Дона, Придорожный, Шасла } \\
\text { мускатная, Эльф }\end{array}$ \\
\hline 8,0 & $\begin{array}{l}\text { Виерул-59, Илья, Мускат дербентский, Памяти Вердеревского, } \\
\text { Памяти Смирнова }\end{array}$ \\
\hline 7,9 & Баклановский \\
\hline 7,8 & Осенний розовый, Ромулус \\
\hline 7,7 & Аку-Аку, Галан, Зоревой, Матрешка, Русмол \\
\hline 7,6 & V-52-16, Восторг красный, Гезен даи, Новоукраинский ранний \\
\hline 7,4 & Бессергеневский № 10 \\
\hline 7,3 & Ефремовский \\
\hline 7,2 & Бурый \\
\hline 7,1 & Шилохвостый \\
\hline 7,0 & Хатал баар \\
\hline
\end{tabular}


Плодоводство и виноградарство Юга России № 65(5), 2020 г.

Наиболее высокие дегустационные оценки получили сорта: Кишмиш лучистый, Сублима сидлис (9,0 баллов), Арсеньевский, Кишмиш розовый, Памяти Негруля (8,9 балла), Золотой Дон (8,8 балла), Валентина, Мечта, Памяти Лазаревского (8,7 балла), Надежда АЗОС, Оли коки, Памяти Кострикина ( 8,6 балла).

Самые низкие дегустационные оценки получили аборигенные дагестанские и донские сорта - Хатал баар (7,0 балла), Шилохвостый (7,1 балла), Бурый (7,2 балла), Ефремовский (7,3 балла), Бессергеневский № 10 (7,4 балла).

Были проведены промеры гроздей и ягод, определена средняя масса 1 ягоды у 52 изучаемых коллекционных сортов (табл. 2). Наиболее крупные грозди были у сортов: Валентина, Октябренок, Мускат дербентский, Заря Несветая, Аку-Аку (длина грозди 24 см и более).

Таблица 2 - Промеры гроздей и ягод (среднее за 2017-2019 гг.)

\begin{tabular}{|c|c|c|c|c|c|c|}
\hline \multirow{2}{*}{ Cорт } & \multicolumn{2}{|c|}{ Размер грозди, см } & \multicolumn{3}{|c|}{ Размер ягод, мм } & \multirow{2}{*}{$\begin{array}{c}\text { Средняя } \\
\text { масса } \\
1 \text { ягоды, г }\end{array}$} \\
\hline & длина & ширина & длина & ширина & диаметр & \\
\hline 1 & 2 & 3 & 4 & 5 & 6 & 7 \\
\hline R-91 & 16,5 & 10,6 & 17,2 & 16,6 & 16,9 & 3,2 \\
\hline $\mathrm{V}-52-16$ & 18,7 & 12,1 & 23,2 & 17,2 & 20,2 & 4,6 \\
\hline Агадаи & 20,2 & 10,9 & 20,4 & 17,3 & 18,9 & 3,4 \\
\hline Аку-Аку ${ }^{*}$ & 24,0 & 13,2 & 20,8 & 18,2 & 19,5 & 4,9 \\
\hline Ананасный ранний & 16,0 & 13,0 & 18,7 & 17,5 & 18,1 & 3,7 \\
\hline Арсеньевский* $^{*}$ & 17,2 & 11,0 & 20,7 & 12,5 & 16,6 & 2,6 \\
\hline Аскери $^{*}$ & 18,0 & 11,2 & 19,2 & 15,7 & 17,5 & 2,9 \\
\hline Барт & 21,6 & 15,0 & 27,3 & 21,6 & 24,5 & 7,9 \\
\hline Блек роуз ${ }^{*}$ & 18,3 & 13,1 & 26,8 & 20,3 & 23,6 & 7,1 \\
\hline Бокальный черный & 23,7 & 16,0 & 26,0 & 18,7 & 22,4 & 5,8 \\
\hline Брумэриу ноу & 19,3 & 13,6 & 22,1 & 19,1 & 20,6 & 4,9 \\
\hline Валентина ${ }^{*}$ & 26,7 & 13,3 & 33,9 & 22,3 & 28,1 & 11,5 \\
\hline Виерул - 59 & 17,7 & 11,9 & 24,4 & 15,3 & 19,9 & 3,8 \\
\hline Восторг & 19,5 & 12,4 & 21,3 & 18,2 & 19,8 & 4,3 \\
\hline Гезен даи & 18,6 & 10,2 & 20,0 & 15,3 & 17,7 & 3,4 \\
\hline Геркулес & 20,8 & 12,0 & 22,5 & 19,6 & 21,1 & 5,4 \\
\hline Голден мускат & 20,2 & 12,1 & 22,2 & 18,5 & 20,4 & 5,1 \\
\hline Долорес & 18,8 & 13,0 & 20,9 & 20,6 & 20,8 & 5,5 \\
\hline Заря Несветая ${ }^{*}$ & 24,0 & 17,0 & 23,6 & 21,2 & 22,4 & 7,0 \\
\hline Звездный & 21,7 & 11,1 & 21,2 & 19,8 & 20,5 & 5,1 \\
\hline Золотой Дон & 16,7 & 10,0 & 22,7 & 18,6 & 20,7 & 4,0 \\
\hline
\end{tabular}


Плодоводство и виноградарство Юга России № 65(5), 2020 г.

\begin{tabular}{|c|c|c|c|c|c|c|}
\hline \multicolumn{7}{|c|}{ Продолжение таблицы 2} \\
\hline 1 & 2 & 3 & 4 & 5 & 6 & 7 \\
\hline Кардинал & 18,2 & 10,5 & 25,2 & 21,6 & 23,4 & 6,7 \\
\hline $\begin{array}{l}\text { Кардинал } \\
\text { устойчивый }\end{array}$ & 18,0 & 13,9 & 24,4 & 22,7 & 23,6 & 7,4 \\
\hline $\begin{array}{l}\text { Кишмиш } \\
\text { запорожский }\end{array}$ & 18,6 & 10,6 & 17,0 & 12,9 & 15,0 & 2,1 \\
\hline Кишмиш розовый & 23,0 & 10,9 & 13,9 & 12,4 & 13,2 & 1,5 \\
\hline $\begin{array}{l}\text { Кишмиш } \\
\text { Узбекистан }\end{array}$ & 23,0 & 9,7 & 13,9 & 14,1 & 14,0 & 1,7 \\
\hline Кодрянка & 17,0 & 12,0 & 22,2 & 15,3 & 18,8 & 3,3 \\
\hline Коринка русская & 18,6 & 11,3 & 10,8 & 11,3 & 11,1 & 0,9 \\
\hline Кутузовский & 18,4 & 11,4 & 23,7 & 17,9 & 20,8 & 4,9 \\
\hline Лацу кере & 16,8 & 10,8 & 15,1 & 14,4 & 14,8 & 2,3 \\
\hline Маршальский & 20,3 & 14,0 & 28,1 & 21,7 & 24,9 & 8,3 \\
\hline Молдова & 19,7 & 12,5 & 22,6 & 18,5 & 20,6 & 5,0 \\
\hline $\begin{array}{l}\text { Мускат } \\
\text { дербентский }\end{array}$ & 24,2 & 11,4 & 20,1 & 18,8 & 19,5 & 4,7 \\
\hline Надежда АЗОС & 20,8 & 14,2 & 27,9 & 22,5 & 25,2 & 8,1 \\
\hline Октябренок & 24,4 & 20,7 & 22,8 & 20,5 & 21,7 & 6,2 \\
\hline Оли коки & 19,8 & 12,8 & 23,1 & 23,0 & 23,1 & 6,6 \\
\hline $\begin{array}{l}\text { Памяти } \\
\text { Вердеревского }\end{array}$ & 21,9 & 13,1 & 27,5 & 18,4 & 23,0 & 5,4 \\
\hline $\begin{array}{l}\text { Памяти } \\
\text { Лазаревского }\end{array}$ & 19,6 & 13,8 & 24,9 & 20,9 & 22,9 & 6,8 \\
\hline Ромулус & 12,8 & 7,4 & 14,7 & 13,1 & 13,9 & 1,9 \\
\hline Рузбари ${ }^{*}$ & 12,5 & 7,3 & 19,0 & 14,2 & 16,6 & 3,0 \\
\hline Русмол & 16,7 & 11,4 & 27,5 & 21,6 & 24,6 & 8,1 \\
\hline $\begin{array}{l}\text { Скоренский } \\
\text { красный }\end{array}$ & 16,6 & 10,5 & 26,2 & 18,8 & 22,5 & 5,2 \\
\hline Сублима сидлис & 18,8 & 13,8 & 21,1 & 18,8 & 20,0 & 4,8 \\
\hline Талисман & 14,2 & 9,4 & 23,4 & 19,6 & 21,5 & 5,6 \\
\hline TacoH & 18,0 & 11,0 & 22,5 & 16,8 & 19,7 & 4,2 \\
\hline Томайский & 15,0 & 11,0 & 24,2 & 18,2 & 21,2 & 4,8 \\
\hline Фахри ${ }^{*}$ & 15,0 & 11,0 & 26,0 & 20,5 & 23,3 & 6,3 \\
\hline Хатал баар & 17,5 & 10,3 & 15,3 & 15,4 & 15,4 & 2,1 \\
\hline Химрод $^{*}$ & 14,0 & 8,0 & 15,0 & 12,8 & 13,9 & 1,8 \\
\hline Хоп халат & 23,7 & 11,1 & 17,4 & 16,7 & 17,1 & 3,0 \\
\hline Хоца цибил & 16,0 & 9,3 & 17,6 & 17,7 & 17,7 & 3,6 \\
\hline Эйнсет сидлис & 17,6 & 9,7 & 15,1 & 14,1 & 14,6 & 1,8 \\
\hline
\end{tabular}

Примечание: * сорта изучались 1 год (2019 г.)

Ранее нами (Новикова, Наумова, 2019) методом анализа главных компонент удалось выявить, что главным дифференцирующим фактором сор- 
тов Донской ампелографической коллекции им. Я.И. Потапенко (на примере фрагмента из 109 сортов, за 1981-2017 гг. наблюдений) является крупность (т.е. размер) грозди, вторым - урожайность, третьим - срок созревания [23]. Наибольшая средняя масса ягоды была у сортов: Валентина $(11,5$ г), Маршальский (8,3 г), Надежда АЗОС, Русмол (8,1 г), Барт (7,9 г), Кардинал устойчивый $(7,4$ г), Блек роуз (7,1 г), Заря Несветая $(7,0$ г).

Наименьшая масса ягоды (менее 2 г) была у 6 бессемянных сортов: Ромулус (1,9 г), Химрод и Эйнсет сидлис $(1,8$ г), Кишмиш Узбекистан $(1,7$ г), Кишмиш розовый $(1,4$ г), Коринка русская $(0,9$ г).

По размеру ягод (диаметр) сорта ранжированы в таблице 3. Очень крупные ягоды (диаметр более 23 мм) были у 10 сортов: Валентина, Надежда АЗОС, Маршальский, Русмол, Барт, Кардинал устойчивый, Блек роуз, Кардинал, Фахри, Оли коки.

Таблица 3 - Ранжирование изучаемых сортов винограда по размеру ягод

\begin{tabular}{|c|l|}
\hline $\begin{array}{c}\text { Размер ягоды } \\
\text { (диаметр, мм) }\end{array}$ & \multicolumn{1}{|c|}{ Сорт, форма } \\
\hline $\begin{array}{c}\text { Ягоды очень крупные } \\
\text { (диаметр более 23 мм) }\end{array}$ & $\begin{array}{l}\text { Барт, Блек роуз, Валентина, Кардинал, Кардинал } \\
\text { устойчивый, Маршальский, Надежда АЗОС, Оли коки, } \\
\text { Русмол, Фахри }\end{array}$ \\
\hline & $\begin{array}{l}\text { V-52-16, Агадаи, Аку-Аку, Бокальный черный, Брумэриу } \\
\text { ноу, Виерул - 59, Восторг, Геркулес, Голден мускат, } \\
\text { Долорес, Заря Несветая, Звездный, Золотой Дон, } \\
\text { Кодрянка, Кутузовский, Молдова, Мускат дербентский, } \\
\text { Октябренок, Памяти Вердеревского, Памяти Лазарев- } \\
\text { ского, Скоренский красный, Сублима сидлис, Талисман, } \\
\text { Тасоды комайский }\end{array}$ \\
$\begin{array}{c}\text { (диаметр 19-23 мм) } \\
\text { R-91, Ананасный ранний, Арсеньевский, Аскери, Гезен } \\
\text { даи, Кишмиш запорожский, Кишмиш Узбекистан, Лацу } \\
\text { кере, Ромулус, Рузбари, Хатал баар, Химрод, Хоп халат, } \\
\text { Хоца цибил, Эйнсет сидлис }\end{array}$ \\
\hline $\begin{array}{l}\text { Ягоды средние } \\
\text { (диаметр 14-18 мм) }\end{array}$ \\
$\begin{array}{c}\text { Ягоды мелкие } \\
\text { (диаметр 7-13 мм) }\end{array}$ & Кишмиш розовый, Коринка русская \\
\hline
\end{tabular}

Крупные ягоды (диаметром от 19 до 23 мм) были у 25 сортов, среди них 8 сортов селекции нашего института: Аку-Аку, Бокальный черный, Восторг, Долорес, Золотой Дон, Памяти Лазаревского, Талисман, Тасон. Ягоды 
среднего размера были у 15 сортов, мелкие - у двух бессемянных сортов: Кишмиш розовый и Коринка русская.

Качество урожая винограда в период созревания напрямую зависит от массовой концентрации сахаров и органических кислот в соке ягод. Соотношение сахаристости ягод к кислотности - глюкоацидиметрический показатель (ГАП), оптимальное значение которого находится в пределах от 2 до 3, играет решающую роль при определении хозяйственной ценности урожая, направления его использования. Созревание урожая и накопление сахаров в соке ягод винограда зависит от метеорологических условий года. Ранжирование сортов по сахаристости сока ягод представлено в таблице 4, по титруемой кислотности - в таблице 5.

Таблица 4 - Ранжирование сортов винограда по сахаристости сока ягод

\begin{tabular}{|c|c|}
\hline $\begin{array}{c}\text { Сахаристость } \\
\text { сока ягод }\end{array}$ & Сорт, форма \\
\hline \begin{tabular}{|c|} 
Очень высокая \\
(свыше 23 г/100 $\mathrm{cm}^{3}$ )
\end{tabular} & - \\
\hline $\begin{array}{c}\text { Высокая } \\
\left(21-23 \text { г/100 } \mathrm{cm}^{3}\right)\end{array}$ & $\begin{array}{l}\text { Баклановский, Виерул-59, Бессергеневский № 10, Кардинал, } \\
\text { Тасон, Гезен даи, Долорес, Кишмиш розовый, Томайский, } \\
\text { Ромулус, V-52-16, Эйнсет сидлис, Звездный, Мускат дербентский }\end{array}$ \\
\hline $\begin{array}{c}\text { Средняя } \\
\left(18-20 \Gamma / 100 \mathrm{~cm}^{3}\right)\end{array}$ & $\begin{array}{l}\text { Аку-Аку, Арсеньевский, Валентина, Восторг, Восторг красный, } \\
\text { Галан, Геркулес, Ефремовский, Заря Несветая, Золотинка, } \\
\text { Зоревой, Илья, Коринка русская, Краса Дона, Маршальский, } \\
\text { Матрешка, Мечта, Мускат смедеревский, Надежда АЗОС, } \\
\text { Октябренок, Оли коки, Оригинал, Осенний розовый, Памяти } \\
\text { Вердеревского, Памяти Лазаревского, Памяти Негруля, Сублима } \\
\text { сидлис, Хатал баар, Шасла мускатная, Шоколадный, Юбилей } \\
\text { Журавеля }\end{array}$ \\
\hline $\begin{array}{c}\text { Низкая } \\
\left(14-17 \text { г/100 } \mathrm{cm}^{3}\right)\end{array}$ & $\begin{array}{l}\text { Агат донской, Ани, Барт, Бурый, Золотой Дон, Кардинал } \\
\text { устойчивый, Мускат де Кодру, Новоукраинский ранний, Памяти } \\
\text { Кострикина, Победа, Придорожный, Русмол, Талисман, } \\
\text { Шилохвостый }\end{array}$ \\
\hline $\begin{array}{c}\text { Очень низкая } \\
\left(\text { до } 14 \text { г/100 cm }{ }^{3}\right)\end{array}$ & - \\
\hline
\end{tabular}

Рассматривая сорта винограда, представленные на дегустациях свежих ягод, отмечаем, что среди них в отчетный период не было сортов с 
очень высокой сахаристостью сока ягод (свыше 23 г/100 см³). Самая высокая сахаристость отмечена у сортов Мускат дербентский $\left(23\right.$ г/100 см$\left.{ }^{3}\right)$, Звездный $(22,6$ г/100 см³), V-52-16 и Эйнсет сидлис $(22,4$ г/100 см³).

Средняя сахаристость сока ягод (18-20 г/100 см³) была у большинства сортов (52\%), высокая и низкая у $14 \%$ сортов, представленных на дегустации. Сортов винограда с очень высокой и очень низкой сахаристостью на дегустациях не было. Сахаристость сока ягод «среднего сорта» на коллек-

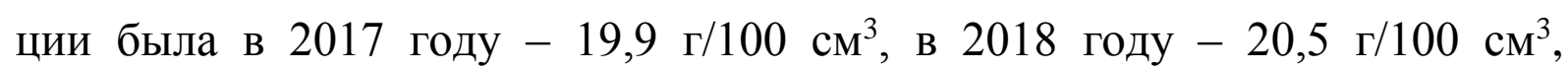
в 2019 году $-19,8$ г/100 $\mathrm{cm}^{3}$.

Таблица 5 - Ранжирование сортов винограда по кислотности сусла

\begin{tabular}{|c|c|}
\hline $\begin{array}{l}\text { Кислотность } \\
\text { сусла }\end{array}$ & Сорт, форма \\
\hline $\begin{array}{c}\text { Очень высокая } \\
\text { (свыше } 12 \text { г/дм }{ }^{3}\end{array}$ & - \\
\hline $\begin{array}{c}\text { Высокая } \\
(10-12 \text { г/дм³ })\end{array}$ & - \\
\hline $\begin{array}{c}\text { Средняя } \\
\left(7-9 \Gamma / \text { дм³ }^{3}\right)\end{array}$ & $\begin{array}{l}\text { V-52-16, Аку-Аку, Арсеньевский, Бессергеневский № 10, Бурый, } \\
\text { Валентина, Восторг, Восторг красный, Долорес, Кардинал } \\
\text { устойчивый, Кишмиш розовый, Новоукраинский ранний, } \\
\text { Октябренок, Оли коки, Памяти Негруля, Придорожный, Ромулус, } \\
\text { Талисман, Хатал баар, Шилохвостый, Шоколадный }\end{array}$ \\
\hline $\begin{array}{c}\text { Низкая } \\
(4-6 \text { г/дм })\end{array}$ & $\begin{array}{l}\text { Баклановский, Агат донской, Ани, Барт, Виерул-59, Галан, Гезен } \\
\text { даи, Геркулес, Заря Несветая, Звездный, Золотинка, Золотой Дон, } \\
\text { Зоревой, Илья, Кардинал, Коринка русская, Краса Дон, } \\
\text { Маршальский, Матрешка, Мечта, Мускат де Кодру, Мускат } \\
\text { дербентский, Мускат смедеревский, Надежда АЗОС, Оригинал, } \\
\text { Осенний розовый, Памяти Вердеревского, Памяти Лазаревского, } \\
\text { Победа, Русмол, Сублима сидли, Тасон, Томайский, Шасла } \\
\text { мускатная, Эйнсет сидлис, Юбилей Журавеля }\end{array}$ \\
\hline $\begin{array}{l}\text { Очень низкая } \\
\text { (до } 4 \text { г/дм³ })\end{array}$ & Памяти Кострикина \\
\hline
\end{tabular}

Титруемая кислотность у большинства изучаемых сортов винограда была низкая - от 4 до 6 г/дм³ (62\%), у $36 \%$ сортов - средняя, среди них 6 сортов селекции ВНИИВиВ-филиал ФГБНУ ФРАНЦ (Аку-Аку, Валентина, Восторг, Восторг красный, Долорес, Талисман). 
Плодоводство и виноградарство Юга России № 65(5), 2020 г.

Очень низкая титруемая кислотность отмечена у одного сорта Памяти Кострикина $(3,8$ г/дм³ $)$. Сортов с высокой и очень высокой кислотностью (от 10 г/дм³ и выше) в отчетный период на дегустациях столового винограда не было.

Bbыводы. Методы оценки качества столовых сортов винограда основаны как на субъективном анализе, так и на инструментальных измерениях, которые коррелируют с органолептическими свойствами и могут использоваться в качестве предикторов потребительской приемлемости.

Органолептическая оценка, кондиции урожая, размерные характеристики сортов и механические свойства важны для понимания конечной ценности свежего винограда.

По данным наших исследований, выделились по комплексу увологических показателей (дегустационная оценка свежего винограда, размеры грозди и ягоды, масса ягоды, кондиции урожая) столовые сорта Валентина, Памяти Негруля, Надежда АЗОС, а также бессемянные сорта Кишмиш лучистый, Сублима сидлис, Арсеньевский.

\section{Литература}

1. Фортов В.Е., Пальцев М.А. Генетические ресурсы растений, животных и микроорганизмов на службе человечества // Вестник российской академии наук. 2017. № 4(87). C. 375-376. DOI:10.7868/S0869587317040156.

2. Анапская ампелографическая коллекция - крупнейший центр аккумуляции и изучения генофонда винограда в России / М.И. Панкин, В.С. Петров, А.А. Лукьянова [и др.] // Вавиловский журнал генетики и селекции. 2018. № 22(1). С. 54-59. DOI 10.18699/VJ18.331

3. Матвеева Н.В., Наумова Л.Г., Ганич В.А. Качество урожая и увологическая характеристика аборигенных донских сортов винограда на коллекции // 125 лет прикладной ботаники в России: сборник тезисов. Санкт-Петербург: ФГБНУ ФИЦ ВИГРР им. Н.И. Вавилова (ВИР), 2019. С. 161-162.

4. Наумова Л.Г., Ганич В.А., Матвеева Н.В. Увологическая оценка донских аборигенных сортов винограда на ампелографической коллекции им. Я.И. Потапенко // Плодоводство и ягодоводство России. 2019. Т. 59. С. 152-161. DOI: 10.31676/2073-4948-201959-152-161

5. Ампелография СССР. М.: Пищепромиздат, 1946. Т. 1. 401 с.

6. Энциклопедия виноградарства. Кишинев: Гл. ред. Молд. Сов. Энциклопедии, 1987. T.3. $271 \mathrm{c}$. 
7. Contador. L., Shinya. P., Infante. R. Texture phenotyping in fresh fleshy fruit // Scientia Horticulturae. 2015. 193. pp. 40-46. DOI: 10.1016/j.scienta.2015.06.025

8. Carreno I., Cabezas J.A., Martínez-Mora C. et al. Quantitative genetic analysis of berry firmness in table grape (Vitis vinifera L.) // Tree Genetics \& Genomes. 2015. 11: 818. DOI:10.1007/s11295-014-0818-x.

9. Стоев К.Д. Физиология винограда и основы его возделывания: Рост и развитие виноградной лозы. София: Изд-во Болгарской Академии наук, Том 2. 1983. 382 с.

10. Магомедов М.Г. Виноград. Основы технологии хранения. СПб: Лань. 2015. $240 \mathrm{c}$.

11. Простосердов Н.Н. Основы виноделия. М.: Пищепромиздат, 1955. 244 с.

12. Простосердов Н.Н. Изучение винограда для определения его использования (увология). М.: Пищепромиздат, 1963. 79 с.

13. Разуваев Н.И. Комплексная переработка вторичных продуктов виноделия. М.: Пищевая промышленность, 1975. 168 с.

14. Агабальянц Г.Г. Избранные работы по химии и технологии вина, шампанского и коньяка. М.: Пищевая промышленность, 1972. 615 с.

15. Ortega-Regules A., Ros-García J.M., Bautista-Ortín A.B., López-Roca J.M., Gómez-Plaza E. Differences in morphology and composition of skin and pulp cell walls from grapes (Vitis vinifera L.): technological implications. // European Food Research and Technology. 2008. 227: 223-231.

16. Letaief H., Rolle L., Gerbi V. Mechanical behavior of wine grapes under compression tests // Am. J. Enol. Vitis. 2008. 59:323-329.

17. Mira de Orduña R. Climate change associated effects on grape and wine quality and production // Food Res. Int. 2010. 43. pp.1844-1855. DOI: 10.1016/j.foodres.2010.05.001

18. Van Leeuwen C., Darriet P. The Impact of Climate Change on Viticulture and Wine Quality // Journal of Wine Economics, 2016. 11(1), 150-167. DOI:10.1017/jwe.2015.21

19. Santos J.A., Fraga H., Malheiro A.C. et al. A Review of the Potential Climate Change Impacts and Adaptation Options for European Viticulture. Applied Sciences. 2020. 10(9) DOI: $10.3390 /$ app 10093092

20. Новикова Л.Ю., Наумова Л.Ю. Тенденции изменений сахаристости и кислотности сортов винограда коллекции ВНИИВИВ им. Я.И. Потапенко // Виноделие и виноградарство. 2013. № 6. С. 54-57.

21. Code des caracteres descriptifs des varietes et especes de Vitis. Paris, 1983.

22. Лазаревский М.А. Изучение сортов винограда. Ростов: Изд-во Ростовского университета, 1963. 152 с.

23. Новикова Л.Ю., Наумова Л.Г. Структурирование ампелографической коллекции по фенотипическим характеристикам и сравнение реакции сортов винограда на изменение климата // Вавиловский журнал генетики и селекции. 2019. Т. 23. № 6. C. 142-149. DOI 10.18699/VJ19.551

\section{References}

1. Fortov V.E., Pal'cev M.A. Geneticheskie resursy rastenij, zhivotnyh i mikroorganizmov na sluzhbe chelovechestva // Vestnik rossijskoj akademii nauk. 2017. № 4(87). S. 375-376. DOI:10.7868/S0869587317040156.

2. Anapskaya ampelograficheskaya kollekciya - krupnejshij centr akkumulyacii i izucheniya genofonda vinograda v Rossii / M.I. Pankin, V.S. Petrov, A.A. Luk'yanova [i dr.] // Vavilovskij zhurnal genetiki i selekcii. 2018. №22(1). S. 54-59. DOI 10.18699/VJ18.331

3. Matveeva N.V., Naumova L.G., Ganich V.A. Kachestvo urozhaya i uvologicheskaya harakteristika aborigennyh donskih sortov vinograda na kollekcii // 125 let prikladnoj botaniki v Rossii: sbornik tezisov. Sankt-Peterburg: FGBNU FIC VIGRR im. N.I. Vavilova (VIR), 2019. S. 161-162. 
4. Naumova L.G., Ganich V.A., Matveeva N.V. Uvologicheskaya ocenka donskih aborigennyh sortov vinograda na ampelograficheskoj kollekcii im. Ya.I. Potapenko // Plodovodstvo i yagodovodstvo Rossii. 2019. T. 59. S. 152-161. DOI: 10.31676/2073-4948-2019-59$152-161$

5. Ampelografiya SSSR. M.: Pishchepromizdat, 1946. T. 1. $401 \mathrm{~s}$.

6. Enciklopediya vinogradarstva. Kishinev: Gl. red. Mold. Sov. Enciklopedii, 1987. T.3. $271 \mathrm{~s}$.

7. Contador. L., Shinya. P., Infante. R. Texture phenotyping in fresh fleshy fruit // Scientia Horticulturae. 2015. 193. pp. 40-46. DOI: 10.1016/j.scienta.2015.06.025

8. Carreno I., Cabezas J.A., Martínez-Mora C. et al. Quantitative genetic analysis of berry firmness in table grape (Vitis vinifera L.) // Tree Genetics \& Genomes. 2015. 11: 818. DOI:10.1007/s11295-014-0818-x.

9. Stoev K.D. Fiziologiya vinograda i osnovy ego vozdelyvaniya: Rost i razvitie vinogradnoj lozy. Sofiya: Izd-vo Bolgarskoj Akademii nauk, Tom 2. 1983. 382 s.

10. Magomedov M.G. Vinograd. Osnovy tekhnologii hraneniya. SPb: Lan'. 2015. $240 \mathrm{~s}$.

11. Prostoserdov N.N. Osnovy vinodeliya. M.: Pishchepromizdat, 1955. $244 \mathrm{~s}$.

12. Prostoserdov N.N. Izuchenie vinograda dlya opredeleniya ego ispol'zovaniya (uvologiya). M.: Pishchepromizdat, 1963. 79 s.

13. Razuvaev N.I. Kompleksnaya pererabotka vtorichnyh produktov vinodeliya. M.: Pishchevaya promyshlennost', 1975. $168 \mathrm{~s}$.

14. Agabal'yanc G.G. Izbrannye raboty po himii i tekhnologii vina, shampanskogo i kon'yaka. M.: Pishchevaya promyshlennost', 1972. 615 s.

15. Ortega-Regules A., Ros-García J.M., Bautista-Ortín A.B., López-Roca J.M., Gómez-Plaza E. Differences in morphology and composition of skin and pulp cell walls from grapes (Vitis vinifera L.): technological implications. // European Food Research and Technology. 2008. 227: 223-231.

16. Letaief H., Rolle L., Gerbi V. Mechanical behavior of wine grapes under compression tests // Am. J. Enol. Vitis. 2008. 59:323-329.

17. Mira de Orduña R. Climate change associated effects on grape and wine quality and production // Food Res. Int. 2010. 43. pp.1844-1855. DOI: 10.1016/j.foodres.2010.05.001

18. Van Leeuwen C., Darriet P. The Impact of Climate Change on Viticulture and Wine Quality // Journal of Wine Economics, 2016. 11(1), 150-167. DOI:10.1017/jwe.2015.21

19. Santos J.A., Fraga H., Malheiro A.C. et al. A Review of the Potential Climate Change Impacts and Adaptation Options for European Viticulture. Applied Sciences. 2020. 10(9) DOI: 10.3390/app10093092

20. Novikova L.Yu., Naumova L.Yu. Tendencii izmenenij saharistosti i kislotnosti sortov vinograda kollekcii VNIIVIV im. Ya.I. Potapenko // Vinodelie i vinogradarstvo. 2013. № 6. S. 54-57.

21. Code des caracteres descriptifs des varietes et especes de Vitis. Paris, 1983.

22. Lazarevskij M.A. Izuchenie sortov vinograda. Rostov: Izd-vo Rostovskogo universiteta, 1963. $152 \mathrm{~s}$.

23. Novikova L.Yu., Naumova L.G. Strukturirovanie ampelograficheskoj kollekcii po fenotipicheskim harakteristikam i sravnenie reakcii sortov vinograda na izmenenie klimata // Vavilovskij zhurnal genetiki i selekcii. 2019. T. 23. №6. S. 142-149. DOI 10.18699/VJ19.551 